\title{
Dealing with Alternatively Organized Workers: Recruitment and Retention Strategies among Danish Shop Stewards
}

1 Anna llsøe

Assistant Professor, FAOS, University of Copenhagen, Denmark ${ }^{1}$

\begin{abstract}
Membership rates of alternative unions that offer individual juridical guidance and assistance but rarely contribute to collective bargaining are increasing in Denmark. Conversely, the overall membership rates of traditional unions that negotiate collective agreements are decreasing. This means that local shop stewards often face a mixed environment of workers in traditional unions and workers in alternative unions at the individual workplace. Surveys have indicated that shop stewards split into two groups when dealing with non-members at the workplace. Half of them choose to represent non-members (pull strategy), whereas the other half choose not to (push strategy). This article presents an explorative case study of the recruitment and retention strategies used by two shop stewards in two different companies with significant groups of alternatively organized workers. A case with sector-level wage setting and a case with local-level wage setting within the manufacturing sector are compared. Results suggest that shop stewards in both types of settings tend to combine push and pull strategies, because they serve different purposes. Push strategies help retain existing members of the traditional unions, whereas pull strategies are necessary to recruit new members. Local-level wage setting seems to offer more opportunities for shop stewards to make use of push and pull strategies than sector-level wage setting. Local negotiators can be efficient organizers, because they are able to demonstrate visible advantages of union membership on a regular and individual basis. However, it is also a high-risk project that among others depends on the support from the local union office.
\end{abstract}

\section{KEY WORDS}

Alternative unions / Traditional unions / Danish Industrial Relations / Organizing / Shop stewards / Wage setting level

\section{Introduction and background}

lthough Danish union densities remain comparatively high, a declining tendency has been observed during the last 15 years (Due et al. 2010; Visser 2006). This development both reflects a rise in the number of workers with no union affiliation at all and a rise in the number of workers organized in alternative unions. In the Danish context, alternative unions refer to unions that offer individual juridical guidance and assistance but rarely contribute to collective bargaining. This means that they are significantly cheaper to join than traditional unions, who invest the majority of their

\footnotetext{
${ }^{1}$ E-mail: ai@faos.dk
} 
resources in collective bargaining activities. Surveys have demonstrated that the cheaper membership fee is one of the most important reasons why workers make the shift from traditional to alternative unions. Another important reason is dissatisfaction with the individual service delivered by the traditional union (Ibsen et al. 2012). Furthermore, the alternative unions seem to attract a lot of young workers, which is a group that traditional unions in Denmark as well as in other countries find it difficult to recruit and retain (Ibsen et al. 2011, 2012; Tailby and Pollert 2011; Visser 2002).

The development in union densities is also evident at the local level. Today, shop stewards who represent the traditional unions increasingly face a complex environment of traditionally organized workers, alternatively organized workers, and unorganized workers on the shop floor. Whereas one in three local shop stewards had unorganized or alternatively organized colleagues in 1998, this was the case for two in three shop stewards in 2010 (Navrbjerg and Larsen 2011). Danish as well as international studies have demonstrated how local employee representatives play an important role in the retention and recruitment of union members (Larsen et al. 2010; Oesch 2012; Pilemalm et al. 2001). Several unions in Denmark and other Western countries have launched initiatives to strengthen this role, for instance, through organizer campaigns (Arnholtz et al. 2012; Badigannavar and Kelly 2005, 2011; Hickey et al. 2010). An increasing number of unorganized and alternatively organized workers therefore mean that shop stewards must focus more of their work on recruiting and retaining union members.

However, it might be difficult for shop stewards to combine certain recruitment and retention initiatives with their other tasks at the workplace. Danish shop stewards are elected among members of the traditional unions at the workplace, and they are only obliged to represent those members. Yet, surveys have indicated that shop stewards split into two groups when it comes to non-members. Approximately half of the shop stewards $(48 \%)$ choose to represent non-members in the same way as members, whereas the other half (39\%) choose not to (Larsen et al. 2010: 99; Navrbjerg and Larsen 2011: 91). How can we explain this answer? A possible explanation might be that many Danish shop stewards are involved in extensive bargaining activities at the company level. A large part of the private sector in Denmark is characterized by local-level wage setting (within the framework of sector-level agreements). Hence, the majority of shop stewards in the private sector need to establish a strong bargaining mandate toward management, which can affect their choice of recruitment and retention strategies.

Previous studies have shown that it is often more difficult for shop stewards and other forms of employee and/or union representatives to coordinate bargaining objectives among the workers than it is for management representatives to coordinate bargaining objectives among the other managers (Ilsøe 2012; Walton and McKersie 1965). The presence of alternatively organized or unorganized workers might make this process of intra-organizational bargaining even more challenging for local shop stewards. If shop stewards depend on a strong bargaining mandate, they may prefer inclusive strategies toward non-members to avoid conflicts among workers. On the contrary, if shop stewards depend less on a strong bargaining mandate, they may feel more free to make use of exclusive strategies toward non-members. The split answer by Danish shop stewards regarding the representation of non-members might therefore be explained by the difference in bargaining activity at the local level, i.e., the wage setting level. 
The aim of this article is to investigate and compare the use of recruitment and retention strategies among local shop stewards in Denmark who face alternatively organized workers at their workplace but operate under different wage setting levels. It asks the questions why shop stewards choose to represent (or not to represent) alternatively organized workers, what this representation includes, and which consequences their choice has for the retention and recruitment of members of the traditional unions. The background analysis presented in the first sections is based on desk research and secondary literature and data. The main part of the analysis is based on explorative case studies at two different manufacturing companies with significant groups of alternatively organized workers. Each case study includes document studies on the company and an in-depth interview with the shop steward representing the largest group of workers in production. A company with local-level wage setting and a company with sector-level wage setting are included in the case study.

\section{Union density decline and the growth of alternative unions in Denmark}

During the last decades, Denmark has been characterized as a best case of organized labor markets (Ilsøe et al. 2007; Traxler 1995). In the 1980s and the 1990s the Danish labor market did not experience significant drops in union densities and in the coverage of collective agreements like many other countries in the Western world. However, after the millennium union densities started to decline also in the Danish case. The overall union density of $73 \%$ in 2000 had decreased to 67\% in 2012 (Due et al. 2012). Manufacturing workers, who are the focus of this article, have typically had one of the better union densities in the private sector in Denmark, but they also experienced a significant decline after the millennium (Due et al. 2010: 100).

The overall union density, however, does not tell us the full story about the trends of disorganization on the Danish labor market. In recent years a new type of union has gained foothold on the Danish labor market, which is included in the general figures on union densities. These are the so-called alternative unions, which offer individual juridical guidance and assistance but rarely negotiate collective agreements. They are cheaper to join than the traditional unions, as they do not contribute to collective bargaining and other activities of the collective bargaining system. Such absence of collective bargaining activities is also characteristic of different forms of "alternative workers organizations" or "quasi-unions" found in other countries (Heckscher and Carre 2006; Hyde 2006). It is, however, important to underline that alternative unions in Denmark recruit members in all types of jobs and sectors. Here, they differ from the so-called "company unions," which are limited to and run by a specific company.

In 2002 a new law on cross-industry unemployment funds created new opportunities for most alternative unions to establish their own unemployment insurance fund and copy this practice from the traditional unions in Denmark (Lind 2009). ${ }^{1}$ The result was that more alternative unions were able to benefit from the so-called Ghent effect, i.e., when unions administer unemployment insurance, this usually contributes positively to the membership rates of the unions (Due et al. 2010; Visser 2002). Furthermore, in 2006, a verdict from The European Court of Human Rights considered closed shop agreements illegal on the Danish labor market (Justesen 2009). This made it possible 
for alternative unions in Denmark to recruit members at more workplaces than before. Today, alternative unions are a serious competition to the traditional unions, as they represent more than $12 \%$ of all union members (or $8 \%$ of all employees) in Denmark (Due et al. 2012). The development in membership rates for the traditional unions and the alternative unions is illustrated in Figure 1.

Figure I: Percentage of employees on the Danish labor market who are members of traditional unions, alternative unions, or without union affiliation 1995-20I2.

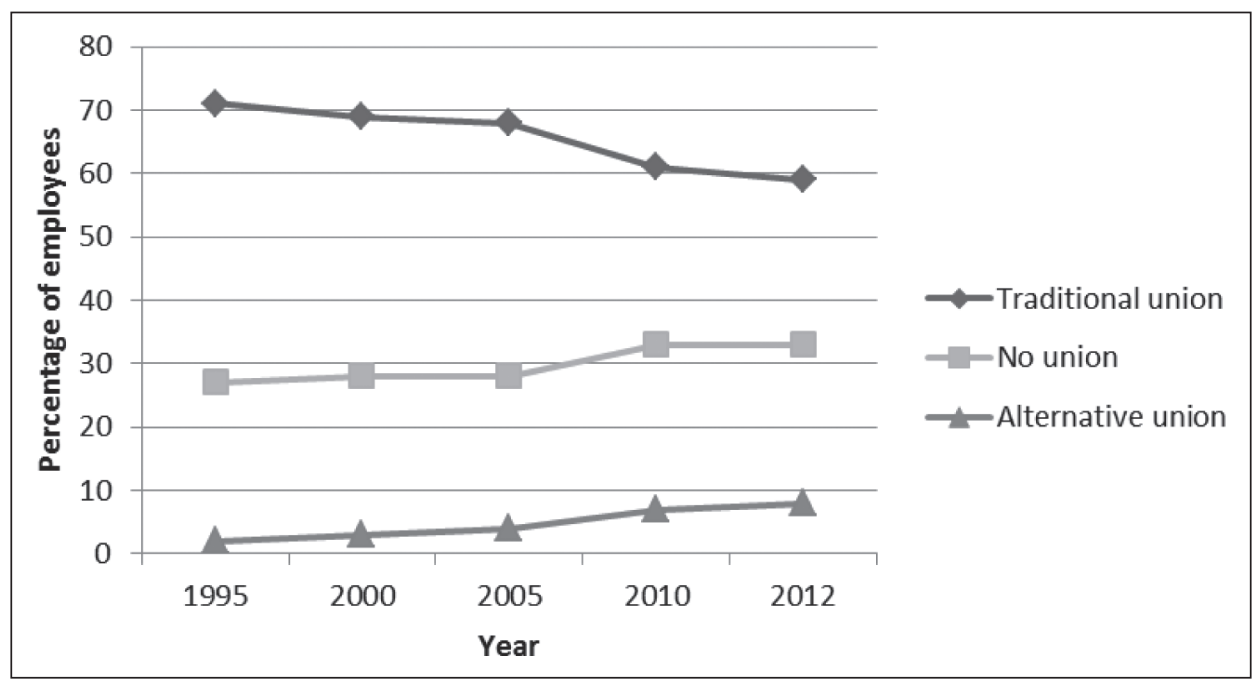

Source: Graph created using figures from Due et al. (2012).

The largest alternative unions in Denmark are The Christian Union (Krifa) and The Union House (Det Faglige Hus). The Christian Union, which has the longest history among alternative unions in Denmark, has about 135,000 ordinary members, whereas The Union House has about $80,000 .^{2}$ The Christian Union developed as a protest to the social-democratic orientation of the traditional unions, whereas The Union House started out as a union for white collar workers but later incorporated self-employed and blue collar workers. Both unions administer their own unemployment insurance fund and have expanded their membership rates significantly in the last decade.

Surveys have shown that the price difference in union membership is the most important reason why members choose to leave one of the traditional unions for an alternative union. Whereas the monthly membership fees of traditional and alternative unemployment insurance funds are very similar (about 60-65 €), the monthly membership fees of the alternative unions are less than half the fees of the traditional unions (10-20€ vs. 45-75 €). Interestingly, the second most important reason to make the shift to an alternative union is dissatisfaction with the individual service delivered by the traditional union (Ibsen et al. 2012). This is in spite of the fact that traditional and alternative unions in principle differ more on the collective services than the individual 
services. Whereas both types of unions offer individual services like juridical guidance and assistance, discounts on various goods, invitations to meetings and courses, and access to supplementary unemployment insurance (that adds on top of the unemployment insurance system), it is only the traditional unions that contribute to the financing and organization of the collective services. The latter include negotiations of collective agreements, resolutions of collective conflicts, social dialogue, and representation of members at the workplace level by local shop stewards (see Table 1 for a comparison of union activities in traditional and alternative unions in Denmark).

Table I Union activities - a comparison of traditional and alternative unions in Denmark

\begin{tabular}{|c|c|c|c|}
\hline & & $\begin{array}{l}\text { Traditional } \\
\text { unions }\end{array}$ & $\begin{array}{l}\text { Alternative } \\
\text { unions }\end{array}$ \\
\hline \multirow[t]{3}{*}{$\begin{array}{l}\text { Union activities } \\
\text { (collective) }\end{array}$} & $\begin{array}{l}\text { - Collective bargaining at the sector level (and } \\
\text { local level) } \\
\text { - Support of industrial conflicts }\end{array}$ & Yes & No* \\
\hline & $\begin{array}{l}\text { - Social dialogue between unions, employers' } \\
\text { organizations, and the state } \\
\text { - Negotiation of tripartite agreements }\end{array}$ & Yes & No \\
\hline & $\begin{array}{l}\text { - Election of union representatives at the } \\
\text { workplace level (shop stewards) that represent } \\
\text { members in local negotiations and cooperation }\end{array}$ & Yes & No \\
\hline \multirow{4}{*}{$\begin{array}{l}\text { Union activities } \\
\text { (individual) }\end{array}$} & - Juridical guidance and assistance & Yes & Yes \\
\hline & - Discounts on insurance, holidays, and shopping & Yes & Yes \\
\hline & - Invitations to courses and meetings & Yes & Yes \\
\hline & $\begin{array}{l}\text { - Supplementary unemployment insurance } \\
\text { (supplementary fee) }\end{array}$ & Yes & Yes \\
\hline $\begin{array}{l}\text { Activities of } \\
\text { unemployment } \\
\text { insurance fund }\end{array}$ & $\begin{array}{l}\text { - Unemployment benefits } \\
\text { - Individual guidance on job seeking and further } \\
\text { training }\end{array}$ & Yes & Yes \\
\hline
\end{tabular}

Source: Author's own research on union activities at the web pages of the following traditional and alternative unions: The Danish Metalworkers' Union (Dansk Metal), The United Federation of Danish Workers (3F), The Danish Food and Allied Workers' Union (NNF), The Christian Union (Krifa), and The Union House (Det Faglige Hus).

* One of the alternative unions in Denmark, The Christian Union, to a limited extent negotiates company-level agreements. However, these agreements only cover a small group of their members.

However, there might be good reasons why employees mainly compare the quality of the individual service - and not the collective service. The employers' organizations on the Danish labor market have argued for years that all workers should be treated equally no matter their organizational status, as this is administratively easier and cheaper for the individual employer (Due and Madsen 2007). This point of view is reflected in the Danish labor market regulation. If a collective agreement is present at the workplace, it is a general rule in the Danish collective bargaining system that non-members are 
covered in the same way as members of the traditional unions (Due et al. 1994, 2010; Ibsen et al. 2011, 2012). This means that the individual worker can join an alternative union, which is cheaper, and still be covered by the collective agreement negotiated by the traditional union. It can be argued that such a choice contains an element of free riding, as the worker will have access to all the gains of the agreement without contributing to the collective bargaining system (Olson 1965). However, the collective agreement coverage also means that it is possible for the individual worker to compare the quality of the individual service delivered by the traditional and the alternative union, respectively. Workers are free to choose the union with the best individual service without losing collective agreement coverage. The competition between traditional and alternative unions is therefore strong on the individual service.

Nevertheless, coverage by collective agreements is not the same as representation by local shop stewards. The alternative unions rarely elect local employee representatives, and only members of the traditional unions are entitled to representation and support by their local shop steward in case of any individual disagreements with management. This puts the assistance and support delivered by local shop stewards at the very center of attention regarding recruitment and retention of members to the traditional unions. Local shop stewards can demonstrate the difference between membership of a traditional and an alternative union in a detectable way for the individual worker who is in need of shop steward support. This is a good argument for traditional unions to assign local shop stewards a key role in the organizing task. As we shall see, there are, however, also counterarguments to this. Danish shop stewards to varying degrees perform collective bargaining at the workplace, and the combination of being an "organizer" and a "negotiator" contains potential role conflicts.

\section{Decentralization of collective bargaining and role conflicts among shop stewards: does this affect recruitment and retention strategies?}

In many countries the story of declining or dropping union densities has been related to a process of decentralization of collective bargaining (Traxler 1995). This relation is not so clear in the Danish case. First of all due to the fact that most employees on the labor market remain covered by sector-level agreements, there is full coverage in the public sector and about $70 \%$ coverage in the private sector (Due et al. 2010: 81). Second, the Danish collective bargaining system always has been characterized by both trends of centralization and trends of decentralization (Due et al. 1994; Ilsøe et al. 2007). The famous September Compromise in 1899 between industry and labor initiated a process, which in the first half of the $20^{\text {th }}$ century led to an institutionalization of negotiations and industrial conflicts at central levels. However, the development was not at the cost of the possibilities for local-level wage setting. Pay has been a matter of company-level bargaining in the metal industry since the beginning of the $20^{\text {th }}$ century, and today many sector-level agreements in the private sector include a large room for maneuver for locallevel negotiations on pay.

However, we find various levels of decentralization within the Danish collective bargaining system and within manufacturing, which is the focus of this article. Wages are mainly negotiated at the sector level in the public sector, whereas the private sector represents a mixture of sector-level and local-level wage setting. The Industrial 
Agreement, ${ }^{3}$ which covers blue collar workers in the metal industry and some other industries, only regulate a relatively low minimum wage on top of which local managers and shop stewards negotiate further wage increases. In comparison, The Collective Agreement for the Food Industry, ${ }^{4}$ which covers workers in a large part of the food industry, stipulates a much higher normal wage, which in most cases is paid to the workers without supplementary negotiations at the local level. These two types of wage setting result in somewhat different working conditions for local managers and shop stewards within manufacturing.

In companies with local-level wage setting, shop stewards typically renegotiate company-level agreements on pay (and other issues) each year, whereas shop stewards in workplaces without local-level wage setting participate in few negotiations. One might therefore expect the presence of alternative organized workers to be more challenging for shop stewards covered by minimum wage agreements, because they more often need to establish a strong bargaining mandate. Thorough case studies at the company level have shown how shop stewards often experience role conflicts between their relations with management and their relations with the worker collective. Often they find it difficult to create compromises that meet the needs and wishes of both sides of the industry, i.e., what Walton and McKersie have characterized as boundary conflicts (Due and Madsen 1972; Lysgaard 1961; Navrbjerg 1999; Walton and McKersie 1965). However, when shop stewards are faced with a worker collective of mixed organizational status, this can also lead to important role conflicts in relation to their constituencies. On the one hand, shop stewards must engage all workers in order to secure peace and agreement among workers and create a strong bargaining mandate toward management. On the other hand, they are not obliged to (and might choose not to) represent alternatively organized workers during negotiations (Due et al. 1994, 2010). Although agreements will cover all workers at the workplace, shop stewards are allowed to negotiate agreements that mainly address the needs and wishes of members of the traditional union. Accordingly, shop stewards can be faced with the challenge of engaging all workers for support of their bargaining mandate and at the same time differentiate their representation of members and non-members. This scenario includes potential role conflicts between workers' expectations to the shop stewards and the services offered by the shop steward (Due and Madsen 1972). Such role conflicts can be characterized as internal conflicts on the employee side (Walton and McKersie 1965). In sum, shop stewards in companies with workers of mixed organizational status potentially are faced with at least two different role conflicts, which might complicate the use of recruitment and retention strategies (see Figure 2):

The question is how these potential role conflicts affect the choice of recruitment and retention strategies among shop stewards. Declining union densities have forced traditional unions in many countries to focus more on how to recruit and retain members, but it remains an open question how recruitment and retention strategies interact with negotiations at the local level. At least two different approaches to potential members have been observed among American and European unions. Many unions have used a "service model," which refers to a strategy of exclusive services at one or more levels of the union. The main idea is to reserve special rights or services to union members in order to make it attractive for non-members to join-and for members to stay (Heery et al. 2000; Turberville 2004). This approach seeks to fight free riding among workers by assigning members concrete benefits of union membership (Olson 1965). However, the 
Figure 2: Potential role conflicts for shop stewards at workplaces with workers in both traditional and alternative unions.

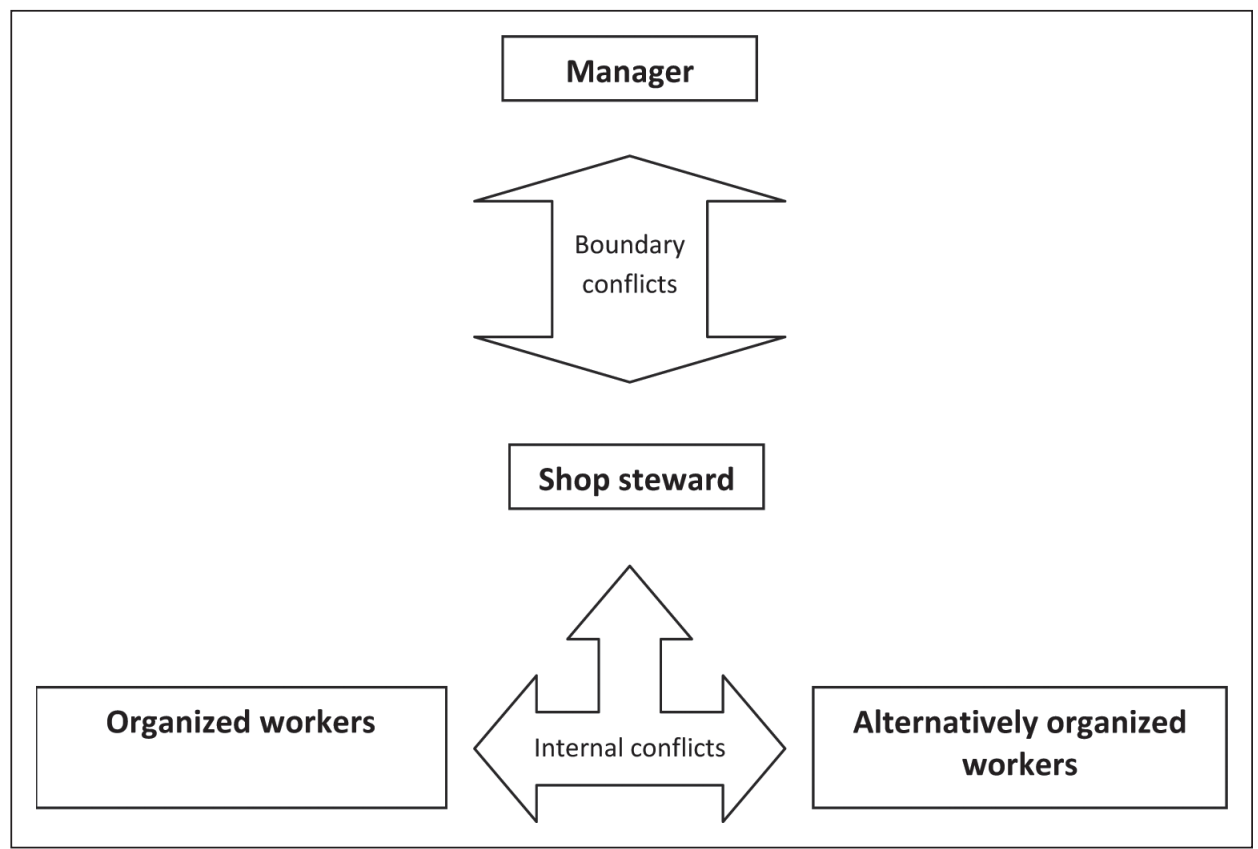

service model has been criticized for its rather passive approach toward unorganized workers and workers in new areas of the economy (Gall 2005). In recent years, many traditional unions have introduced the so-called "organizer model" as an alternative strategy (Hickey et al. 2010). This strategy focuses on the mobilization and empowering of especially unorganized workers to pursue their own interests with union support. The idea is to motivate unorganized workers to join the union by including them in union or union-like activities. If they see what difference it can make in practice to articulate their needs, they should be more likely to sign up. Experiences with the organizer model seem to be mixed-some report about positive effects on recruitment, whereas others conclude that effects are limited (Badigannavar and Kelly 2005, 2011; Gall 2005; Hickey et al. 2010).

The service and the organizer model differ quite distinctively on a number of aspects. The first is more reactive and the second more proactive. The service model was very popular in the early phase of union decline, whereas the organizer model is an increasingly popular approach today. However, the most striking difference between them is their attitude toward non-members. Whereas the organizer model builds on a clear pull strategy (the inclusion of non-members), the service model mainly focuses on push strategies (the exclusion of non-members).

At first glance, it seems possible to argue for both push and pull strategies among shop stewards at the workplace level. As our overview of union services illustrates (see Table 1), free riding might not be the rational choice for workers in companies with shop 
stewards' presence, because only union members are entitled to assistance from their local shop steward. This difference makes it possible for shop stewards to exclude nonmembers from their services-in order to retain current members and recruit new ones. However, some shop stewards might also see an active representation of non-members as a way to recruit new members, because it allows them to demonstrate the concrete advantages of paying the membership fee. The inclusion of non-members could take the form of listening to non-members' needs and wishes during local negotiations, answering questions in relation to collective agreements, or individual representation in certain cases of a disagreement with management.

However, as we have seen, the choice of strategy may not be straightforward. Some shop stewards in Denmark frequently negotiate collective agreements at the workplace, and they may be more concerned about how recruitment and retention strategies affect the solidarity among workers. Push strategies can leave alternatively organized workers dissatisfied and give rise to internal conflicts among workers. Pull strategies might therefore be a more obvious choice for shop stewards who often negotiate at the workplace. This leads us to the following research questions:

1. When do shop stewards choose to represent (or not to represent) alternatively organized workers? What does this representation include and what consequences do their choice of strategy have for the retention and recruitment of traditional union members?

2. Do we observe any difference in the choice of strategy and effects between cases of local-level and sector-level wage setting?

In the case analyses, we will use the concepts of push and pull strategies to identify situations, where the local shop stewards choose to represent or not to represent members of the alternative unions. Furthermore, we will use the concepts to identify different types of push and pull strategies and their effects.

\section{Methods}

The first part of the analysis presented in the background sections rests on desk research and studies of secondary literature and data. The remaining part of the analysis is based on explorative case studies of how two local shop stewards deal with the presence of alternatively organized workers in two different companies.

The case study design with a focus on a limited number of in-depth studies was chosen to reflect the open character of the research questions. Case studies were performed within manufacturing, which is one of the sectors heavily affected by the rise in alternatively organized workers (Ibsen et al. 2011: 115). As mentioned earlier, Danish manufacturing is characterized by two types of wage setting. This means that shop stewards are faced with different demands of collective bargaining at the company level, and perhaps different choices with regard to their strategies toward alternatively organized workers. Accordingly, a case of local-level wage setting (metal industry) and a case of sector-level wage setting (food industry) were included to compare shop stewards' strategies. Both case companies were covered by collective agreements, had shop stewards present, and contained significant groups of organized and alternatively organized workers (see Table 2 for the main characteristics of the two companies). 
Table 2 Overview of main characteristics of the case companies.

\begin{tabular}{ccccccc}
\hline & $\begin{array}{c}\text { Production } \\
\text { workers } \\
\text { (number) }\end{array}$ & $\begin{array}{c}\text { Covered by } \\
\text { collective } \\
\text { agreements }\end{array}$ & $\begin{array}{c}\text { Workers in } \\
\text { traditional } \\
\text { unions } \\
\text { (percentage) }\end{array}$ & $\begin{array}{c}\text { Workers in } \\
\text { alternative } \\
\text { unions } \\
\text { (percentage) }\end{array}$ & $\begin{array}{c}\text { Unorganized Wage setting } \\
\text { workers } \\
\text { (percentage) }\end{array}$ & $\begin{array}{c}\text { (most } \\
\text { important } \\
\text { level) }\end{array}$ \\
\hline Case A & 250 & Yes & $50 \%$ & $50 \%$ & $0 \%$ & Sector level \\
\hline Case B & 150 & Yes & $80 \%$ & $15 \%$ & $5 \%$ & Local level \\
\hline
\end{tabular}

Each case study included document studies of all relevant local agreements, surveys, and reports at the company as well as an in-depth interview with the local shop steward representing the largest group of production workers on-site. Interview guides were prepared on the basis of a secondary analysis of available literature and data and included questions on union membership among the production workers, the development in union membership over the last decade, shop steward representation of workers in traditional unions and of workers in alternative unions, local negotiation and cooperation with management, recruitment and retention of union members, and challenges when dealing with workers in alternative unions. All interviews were transcribed in full before the final analysis, and all citations were translated from Danish to English by the author. The initial strategy of analysis was thematic. First, we performed an open coding of the interviews identifying different push and pull strategies in relation to alternatively organized workers. Second, we went through the interviews again with a more focused coding and located where the different strategies had been used, what the effects were, and which opportunities and challenges there had been in the take-up of each strategy.

\section{Analysis}

The analysis of each case is structured in a short case introduction followed by an analysis of the interview with the shop steward. After the two case analyses, results are summarized and compared.

\section{Case A}

Company A is a Danish food company with approximately 250 production workers. All workers are covered by The Collective Agreement for the Food Industry. After the verdict on closed shop agreements in 2006, the first workers left the traditional union and joined an alternative union. Today, approximately half of the workers are in the alternative unions-especially The Christian Union and The Union House-and half of them are in the traditional unions. All types of workers have joined the alternative unionsyoung, old, men, women, workers with high seniority, and workers with low seniority. The shop steward representing the production workers has been with the company for many years and is a member of the local works council and of the company management board. At present, no local agreements have been concluded between management 
and the shop steward, which reflects that wage setting at the sector level plays the most important role in the food industry. The company has recently been through a number of firing rounds due to increasing competition on the world market. This is also one of the reasons why the company mainly hires workers on temporary contracts.

\section{Strategies toward alternatively organized workers}

The shop steward in company A makes use of both push and pull strategies toward alternatively organized workers. The shop steward highlights pull strategies as more effective recruitment tools than push strategies. Furthermore, push strategies seem more difficult to implement in practice. A closer analysis of the different push and pull strategies used by the shop steward is presented below.

\section{Push strategies: different service levels}

Shop steward A uses a number of push strategies toward alternatively organized workers to motivate them to join the traditional union. The idea is to clarify the difference in services that workers are entitled to receive. One strategy is only to assist members of the traditional union, when the company lays off workers, and to leave alternatively organized workers on their own:

'Last time we were firing people, only six of the fired workers were members of our union. I accompanied them to all meetings and I checked out that everything followed the rules. (...) I did not do anything for the other workers. That was the clear message.' [Shop steward A]

A second push strategy is to refuse to answer difficult questions, when they are raised by non-members. The shop steward does not mind answering simple questions, but questions that need further investigation are rejected:

'If a worker asks a question I do not know the answer to, I will call the union and ask for help, if the worker is in our union. If the worker is member of one of the alternative unions, I will say: "You have to call your union and ask about that".' [Shop steward A]

Thirdly, the shop steward arranges debate sessions for members only. The workers are very interested in them, and it is therefore a clear disadvantage to non-members:

'Tomorrow we are going to have a debate session about early retirement benefits, and somebody will give an introductory lecture. This event is for members only. (...) We must do things like this more often.' [Shop steward A]

However, it is not always easy for the shop steward to implement these push strategies in practice. Some of the workers have been at the workplace for a long time-and so has the shop steward. It is according to the shop steward's experience difficult to use the push strategies mentioned above when it comes to those workers who have a high seniority at the workplace and only recently made the shift from the traditional union to an 
alternative union. Which services are they entitled to? Are they entitled to a better service than newly hired alternatively organized workers? Some of these workers have been the shop steward's colleagues back to the days of piece work, where it was important with a strong solidarity at the assembly line. If one of them had a bad day, the others would work harder to make everybody meet the demands. This creates a role conflict between representing the workplace (workplace solidarity) and representing the union (union solidarity), which makes the take-up of push strategies difficult at the company level:

'It is difficult. It is very difficult. I know, I should offer the same service to a new colleague as to a colleague, I have been working with for 20 years. But it is obvious that I feel different for an old colleague.' [Shop steward A]

\section{Pull strategies: inform and convince through dialogue}

The shop steward does, however, not only use push strategies in relation to alternatively organized workers. Pull strategies are also on the repertoire. One of the pull strategies is to ask newly hired workers whether they are member of the traditional union, and explain the advantages of such membership. However, the shop steward uses this strategy in a reflexive way. Many new workers are on temporary contracts, and the shop steward understands if they want to wait and see until they get an open-ended contract:

'When I speak with new workers, I ask them if they are in a union, and most of them are. Then I tell them that we prefer that they join our union, because it strengthens our bargaining power at the workplace. Some of them have been with the alternative unions for a long time. If they only are hired for a shorter period of time, I often tell them: "We will get back to it, if you get a permanent position".' [Shop steward A]

As regards the push strategies, the difference in seniority among workers creates additional role conflicts for the shop steward. On the one hand, the shop steward is a union representative and should help recruit new members to the union (union solidarity). On the other hand, the shop steward represents workers and should reflect on what is best for them-also when it comes to workers on temporary contracts. Is it fair to make a worker join the traditional union, if the worker only has a contract on a few months? The worker might after his/her current job find a new job in a completely different sector, where other traditional unions represent workers during negotiations. Here, the shop steward reflects on the interest of those individual workers who move between workplaces and take on different temporary jobs (worker solidarity).

Another pull strategy is to offer all workers an opportunity to give input to the next collective bargaining round at the sector level. The local union office and the shop steward has informed all workers about the current content of the collective agreement and conducted a survey on their wishes to the content of a future collective agreement. This inclusion of non-members in the collective bargaining process might help workers understand the advantages of having a strong traditional union at the workplace:

'We asked people what they wanted to include in the collective agreement. The survey was given to all workers, and less than half replied. (...) To encourage people to participate it 
was possible to win a holiday trip. One of the workers who won was not member of our union. It was an attempt to provoke the members of the alternative unions and say: "You are not a member of our union, and you should not be able to participate, yet, you have won". (...) Many workers complain that the union is invisible on the shop floor. This was a way to make ourselves more visible.' [Shop steward A]

\section{Critique of the local union office}

On top of the push and pull strategies mentioned above, which are directed toward the alternatively organized workers, the shop steward in company A has found it necessary to develop an additional strategy regarding the recruitment and retention of union members directed at the union. Many workers have told the shop steward that they have left the traditional union due to dissatisfaction with the individual service delivered by the local union office. Therefore, the shop steward has developed a strategy of contacting the local union office directly and to make them aware of every mistake that they do. The aim is to prevent more workers from joining the alternative unions:

'The reason why members have shifted to the alternative unions is that our union is too expensive and that members have not received a proper service. I am sorry, but I have to tell it like it is. (...) It is about guidance and counseling. People can call the union three times and get three different answers. That is not OK. I really try to call the union every time it happens and tell them: "That is not OK. If you want new members, you have to make sure that it works". [Shop steward A]

\section{Case B}

Company B is a Danish machine company with approximately 150 production workers. The demand for the company's products has been on the way up the last couple of years and management plans to hire new workers on open-ended contracts. All production workers are covered by The Industrial Agreement. After the verdict on closed shop agreements in 2006, the first workers joined the alternative unions leaving the traditional unions. Today, approximately $15 \%$ of the workers are in the alternative unions-especially The Union House-and $80 \%$ are members of the traditional unions. Both young and old, male and female workers, and workers with high and low seniority have made the shift. The shop steward representing the production workers has been with the company for many years and is a member of the local works council and of the board of the local union office. Management and the shop steward have concluded several local agreements on pay, working time, and fringe benefits. Local-level wage increases are typically negotiated every year. This reflects the wage system in the metal industry, where only a minimum wage is negotiated at the sector level.

\section{Strategies toward alternatively organized workers}

As in company A, the shop steward in company B makes use of both push and pull strategies toward alternatively organized workers. Local negotiations in Case B seem to offer 
more opportunities for using both push and pull strategies than in Case A. However, it also seems to make the implementation of push strategies even more challenging. The following presents a detailed analysis of the different strategies used.

\section{Push strategies: club members only-but who are the members?}

Shop steward B uses a number of push strategies, which resemble those used by shop steward A. One of the push strategies is not to discuss any union matters with workers in the alternative unions and to refuse to answer any questions on union matters. However, there is a knowledge gap among the alternatively organized workers. Most of them think they are entitled to the same service from the shop steward as members of the traditional unions. This has led to confrontations in the local union club, where alternatively organized workers wanted to attend a meeting on local negotiations on pay. However, the shop steward did not accept this attempt:

'We did not exclude them in the first place. They have excluded themselves from the negotiations. And then they show at the club meeting. I started the meeting by saying: "Welcome to the club meeting. This is a legal club meeting, and I can see that some of the people present are not members of the club. Can you tell me, why you are here?”. Then a man got up and said that they had the same rights as everybody else to participate in meetings on local negotiations on pay. I told him that they did not have the same rights. If they did not want to leave, I would close my computer and leave. Then they left. They were very angry and complained to management afterwards. (...) They wanted their own shop steward, because I did not represent them. But I did not do anything illegal. I just think I am being fair to those members, who pay to the traditional unions. They pay more every month, and therefore they have certain rights.' [Shop steward B]

This example shows how local negotiations on pay in fact can lead to an internal conflict between organized and alternatively organized workers at the workplace. Such a conflict makes the intra-organizational bargaining process more challenging and vulnerable for the shop steward. However, it also supplies the shop steward with an opportunity to demonstrate a clear difference between organized and alternatively organized workersan opportunity that local shop stewards with little bargaining activity do not have.

Shop steward B underlines that the strategy of "club members only" rests on an important precondition. It is not possible to make a sharp distinction between members and non-members, unless you are aware of the union affiliation of each individual worker. Therefore, the shop steward has worked intensively on creating a map of the organizational status of all workers at the company. This push strategy has included calling union offices and interviewing non-members at the workplace, and it is an ongoing time-consuming task:

'When I was elected as shop steward it was a mess. I did not know who belonged to the union or not. My first move was to ask the company about the civil registration numbers on all our workers. Then I went to the local union office and asked, who of these workers are members. I got a number of lists and I worked my way through them. Some of our workers were on none of those lists. Then I went for a walk around the company and 
asked those workers, which union they belonged to. Some said: "I do not belong to any unions". Others said: "I am a member of The Union House". And then I wrote that down, and I have kept it updated ever since.' [Shop steward B]

\section{Pull strategies: education and conversion}

According to the shop stewards' experience, most alternatively organized workers think they are entitled to exactly the same shop steward representation as workers in the traditional unions. The shop steward thinks this is problematic-not only when workers have to decide whether or not to join the union but also with regard to the daily work of the shop steward, because it can contribute to conflicts between shop stewards and alternatively organized workers. After the confrontation at the club meeting, the shop steward therefore developed a strategy to teach all workers about the collective agreement and the differences between traditional unions and alternative unions:

'After that incident their behavior was completely unacceptable. One of the workers who I asked to leave the club meeting had ignored me ever since. I took him into my office and asked him: "What is going on?". He told me. Then I said: "This is what I do, and what I pay for. Therefore your behavior was not acceptable.” I explained it to him in detail. Then he started to realize, why I did it. I promised him that I would arrange a meeting for all workers no matter their union status, and I would explain the collective agreement to them. Which benefits workers obtain from the agreement, and what the advantages of union membership are. I arranged the meeting and more than 100 workers showed. I showed them a power point on how much it costs to join the union per week and how many benefits they obtain from that. (...) I did it, because I was fed up. The trouble after the club meeting really got to me. Then I thought, if this anger is due to a lack of information, I should give them that information. That is why I did it. (...) Lack of information often contributes to that workers choose the alternative unions over the traditional ones.' [Shop steward B]

A later pull strategy has been to convert workers. Here the map of organizational status and the networks created when drawing it have been very useful. Now the shop steward has an agreement with the local union office that they call if someone wants to shift to the alternative union. Then the shop steward can address this worker and have a talk with $\mathrm{him} / \mathrm{h}$. This agreement with the local union office also helps updating the map which is an important job if the strategy of "club members only" should work in the future:

'If somebody in my company wants to leave our union, the local union calls me, and then I usually ask the worker: "I have heard that you have left the union. Why?" Then he gives me an answer. Once I made a worker go back to our union. The union always calls me, before they hit the button, so I can talk with the worker. (...) I always tell the workers who want to leave: "Think about this and this as well. You might need us." In one case, this made the worker stay.' [Shop steward B]

Another situation where it has shown possible for the shop steward to convert alternatively organized workers is in relation to individual negotiations. In a recent case, one of the line managers advised the shop steward to negotiate an individual solution for 
an alternatively organized worker-although the shop steward was not obliged to do it. The aim was to convince the alternatively organized worker of the concrete benefits of being represented by a local shop steward:

'We had four workers who had a lot of hours on their time accounts. The crisis came and we had to do work-sharing, but before we could do that these workers had to take all their banked hours as time off in lieu. However, it was not possible to take all this time off. We therefore negotiated a special solution for each of them. One of the workers belonged to an alternative union, and I said I do not want to help him—only the other three. Then a line manager gave me a good advice, and I said: “Okay, I will help all four workers". I did, and afterwards I took the alternatively organized worker aside and said to him: "Do you see the difference?". He said: "Yes, just give me an application form". Then he joined our union. This experience has made me think. I have been very tough when it comes to not helping out alternatively organized workers. I think joining the alternative unions is letting all your colleagues down. Here I was saying: "Okay, if can do a good deed and go ask them, if they see the difference, they might join the union".' [Shop steward B]

Again, local negotiations seem to offer the shop steward in company B additional potential for recruiting members to the traditional union than the shop steward in company A has access to. However, shop steward B agrees with shop steward A that the first entrance to the company is the most important possibility of recruiting members to the traditional union. It is easier to recruit workers when they recently have been hired:

'I have moved a lot of workers from the alternative unions to the traditional unions. I think we have moved about 20 workers. (...) But it is always more difficult to convert workers, who have been here for some time. When they have made a decision, it is very difficult to make them change it. I have succeeded in converting a few, but it is much easier to make an impact on newly hired workers.' [Shop steward B]

Therefore the shop steward and the local managers have agreed on asking all new workers about their union status. Furthermore, the shop steward shows them around and informs them about the difference in the services delivered, when joining and when not joining the union.

\section{Summary of analysis}

The shop steward in company A and the shop steward in company B have dealt with alternatively organized workers in their companies for some time. Shop steward A (who rarely negotiates local agreements) makes use of both push and pull strategies toward workers in alternative unions. Shop steward B (who often negotiates local agreements) also seems to combine both types of strategies. In fact, shop steward A and shop steward $\mathrm{B}$ tend to use some of the same push strategies and some of the same pull strategies. These results suggest that wage setting levels do not determine shop stewards' overall choice of inclusive and exclusive strategies toward alternatively organized workers. Nevertheless, our comparison indicates that local negotiations offer more opportunities for member recruitment-as well as impose larger challenges on shop stewards. It is possible to 
identify two different forms of push strategies and two different forms of pull strategies across the two cases studied.

\section{Push strategies compared}

Both shop stewards used different forms of push strategies toward alternatively organized workers. Push strategies are considered fair to those workers who pay the higher fee to the traditional unions, and are used to retain existing union members. One of these strategies relates to situations where shop stewards take on the role of a policeman (see Table 3 for an overview of push/pull strategies and shop steward roles). Here, shop stewards correct behavior by the individual alternatively organized worker that exceeds

Table 3 Push and pull strategies toward alternatively organized workers identified in the case analyses.

\begin{tabular}{|c|c|c|c|c|}
\hline & \multicolumn{2}{|c|}{ Push strategies } & \multicolumn{2}{|c|}{ Pull strategies } \\
\hline & Policeman & Researcher & Missionary & Teacher \\
\hline Case A & $\begin{array}{l}\text { Do not answer } \\
\text { difficult questions from } \\
\text { alternatively organized } \\
\text { workers } \\
\text { Do not assist } \\
\text { alternatively organized } \\
\text { workers when fired } \\
\text { Do not invite } \\
\text { alternatively organized } \\
\text { workers to debate } \\
\text { sessions }\end{array}$ & & $\begin{array}{l}\text { Convince new work- } \\
\text { ers on open-ended } \\
\text { contracts about the } \\
\text { advantages of the } \\
\text { traditional union }\end{array}$ & $\begin{array}{l}\text { Inform all workers } \\
\text { about the collective } \\
\text { agreement } \\
\text { Ask all workers } \\
\text { about input to } \\
\text { collective bargaining }\end{array}$ \\
\hline Case B & $\begin{array}{l}\text { Do not answer ques- } \\
\text { tions from alternatively } \\
\text { organized workers } \\
\text { Do not discuss union- } \\
\text { related issues with } \\
\text { alternatively organized } \\
\text { workers } \\
\text { Throw alternatively } \\
\text { organized workers out } \\
\text { of local club meetings } \\
\text { on negotiations }\end{array}$ & $\begin{array}{l}\text { Keep record of the } \\
\text { exact union status } \\
\text { and unemployment } \\
\text { insurance status of all } \\
\text { workers (calling union } \\
\text { offices; asking workers } \\
\text { on the shop floor) }\end{array}$ & $\begin{array}{l}\text { Help new workers } \\
\text { and convince them } \\
\text { of the advantages of } \\
\text { joining the traditional } \\
\text { union } \\
\text { Ask organized work- } \\
\text { ers who want to join } \\
\text { the alternative unions } \\
\text { why - and convince } \\
\text { them to stay } \\
\text { Negotiate individual } \\
\text { solutions for alterna- } \\
\text { tively organized work- } \\
\text { ers and recommend } \\
\text { union membership } \\
\text { afterward }\end{array}$ & $\begin{array}{l}\text { Inform all workers } \\
\text { about the collective } \\
\text { agreement }\end{array}$ \\
\hline
\end{tabular}


what they are entitled to as non-members. Shop stewards refuse to answer questions and/or discuss union-related issues (Case A and B), they do not invite non-members to debate sessions (Case A), or they throw alternatively organized workers out of club meetings on negotiations of pay (Case B). The last action is only an option for shop steward B, as shop steward A rarely negotiates. However, policing is difficult and might not be respected, unless it rests on correct information. Therefore, one of the shop stewards has also taken on the role as a researcher and spends a lot of time on creating and updating an exact map of the union status of all workers at the workplace (Case B).

\section{Pull strategies compared}

Both shop stewards underline that pull strategies are more successful than push strategies when it comes to attracting new union members. The pull strategies used in the cases studied fall in two groups. The most effective strategy when it comes to member recruitment seems to be when shop stewards act as a missionary and show workers the benefits of shop steward representation in practice. Their actions must have an individual and concrete character to demonstrate the personal advantages of membership for the worker in question. To the shop stewards' experience, the easiest way to convince workers of the advantages of joining the traditional union is to convert them when they have just been hired (Case A and B). Therefore, the first talk between worker and shop steward and the initial help offered is crucial. One of the shop stewards has also succeeded in converting workers who have been with the company for many years. This was among others done by negotiating an individual solution for an alternatively organized worker and asking him to join the traditional union afterward (Case B). Here, local negotiations supply shop steward B with larger opportunities for recruitment than shop steward A has access to.

Another important pull strategy is when shop stewards take on the role as a teacher. According to the shop stewards, workers do not know the content of the collective agreement that covers their workplace and they know little about union activities and union influence. Both shop stewards have worked on raising the level of information by distributing written material (Case A) or by presenting the content of the collective agreement at a big meeting for all workers (Case B). One of them has even asked all workers, including the alternatively organized workers, for input to upcoming negotiations in a survey (Case A). The teacher does not seem to be as effective as the missionary when it comes to recruiting new members. However, this strategy has another important function. Shop steward B uses teaching as a way of restoring the relationship with the alternatively organized workers after the policeman has been in action. Policing can create internal conflicts on the employee side, which potentially makes it more difficult for the shop steward to collect support from the employees. This is a serious risk for a shop steward like shop steward B who often negotiates.

\section{Conclusion}

Surveys have indicated that Danish shop stewards split in two groups when it comes to alternatively organized and unorganized workers-half of the shop stewards choose 
to represent them (pull strategy) and half of them choose not to represent them (push strategy). However, our two explorative case studies of shop stewards' strategies toward alternatively organized workers suggest that the two strategies are not exclusive, but are used simultaneously for different purposes.

The analysis indicates that shop stewards use push strategies in order to retain current members of the traditional unions. Pull strategies seem to be used as a recruitment instrument. However, pull strategies can also be used to cope with unwanted side effects of push strategies. This was especially clear in the case where the shop steward often negotiated collective agreements (Case B). Here, push strategies contributed to the creation of internal conflicts on the employee side that had to be solved, before they became a threat to the shop stewards' local bargaining mandate. The example indicates that pull strategies have important functions, when local shop stewards combine recruitment activities with intra-organizational bargaining activities.

Two different push strategies (policeman and researcher) and two different pull strategies (missionary and teacher) are to varying degrees used in the case companies. Some of the strategies seem to be directed toward the total worker collective (researcher, teacher), whereas others are targeted toward individual workers (policeman, missionary). Our studies suggest that local negotiations may enhance the opportunities for shop stewards" use of individual and more "activist-oriented" strategies (Chang 2005). Bargaining activities create additional possibilities to demonstrate the benefits of local-level representation in practice by including (missionary) or excluding (policeman) individual workers. However, results indicate that recruitment strategies with a collective character in general might be easier to implement than individual and activist-oriented strategies. The latter seem to impose larger challenges on the shop steward. This is not only true for shop stewards with intensive bargaining activities that depend on a strong local bargaining mandate. Other factors might interplay with the take-up of push and pull strategies that are targeted toward individual workers.

\section{Worker seniority: temporary workers and older colleagues}

Certain groups of employees seem to impose additional role conflicts on local shop stewards that seek to recruit and retain union members. Company A mostly hires new workers on temporary contracts. This makes the shop steward hesitate to do missionary work toward newly hired workers. Many of these workers will stay in the peripheral group of workers at the company, before they move on to another job, and the shop steward does not think it is fair to convince such workers to join the traditional union, which it oriented to a certain line of business (Atkinson 1987; Marsden 2004). In other words, short contracts create a role conflict for the shop steward between representing the interest of such workers (who might find a new job in a completely different industry) and representing the interest of the union. This imposes a dilemma between worker solidarity (solidarity with temporary workers) and union solidarity (solidarity with the union).

At the same time many workers at company A have a very high seniority (20-30 years), and this raises other concerns for the shop steward. A significant group of these workers has moved from the traditional union to an alternative union, but some of them are old colleagues that has helped the shop steward for many years at the assembly line and vice versa. The shop steward feels it is difficult to stop helping 
these workers with union-related issues, i.e., to act as a policeman. When it comes to the question of union status, shop stewards are expected to show union solidarity. However, they still have to deal with a workplace solidarity among their colleagues, which might transcend their union status, because everybody depends on this solidarity in the daily working life. In sum both workplace solidarity with old colleagues and worker solidarity with new workers on temporary contracts question the shop stewards solidarity with the traditional union in company A.

\section{Local union offices: shop steward support and member service}

In Case B, the local union office supplies the shop steward with help and support, which improve opportunities for recruitment and retention of union members. This cooperation with the local union office makes it easier for the shop steward to target individual and activist-oriented strategies like the policeman or the missionary toward the alternatively organized workers. However, the local union office seems to act quite differently in Case A. Here, the shop steward often finds it difficult to get the support needed from the local union. Furthermore, and more importantly, workers in the traditional union do not seem to receive the help they are entitled to from the local union office. As mentioned earlier, workers are covered by the collective agreement no matter their union status, and therefore workers mainly compare the quality of individual services offered by the traditional union and the quality of the individual services offered by the alternative union (see Table 1). In this case, the better performance by the alternative unions on the individual services makes it difficult for the shop steward to use pull strategies and recruit new members to the more expensive traditional union. The poor performance of the traditional union is especially challenging for the shop steward, because wage setting takes place at the sector level. The shop steward does not negotiate any local agreements and therefore cannot use this additional instrument to demonstrate a difference between the traditional and the alternative unions.

\section{Discussion: Shop stewards as organizers-a hidden potential?}

Traditional unions in the Western world find it increasingly difficult to recruit and retain members. This is also the case in Denmark, where membership rates are declining among traditional unions that participate in collective bargaining and social dialogue. Furthermore, alternative unions that offer individual juridical guidance and assistance at a cheaper price are growing. This increases the competition between unions. Collective agreements cover all employees at workplaces, where they are present. Accordingly, it is possible for workers to free ride on agreement coverage and to buy the individual service cheaper at the alternative unions instead. However, our analysis points at some of the limitations to free riding. It is not possible to free ride on the representation by the local shop steward. If a shop steward is present, it might therefore be a more rational choice for the individual worker to stay in the traditional union, because it entitles $\mathrm{him} / \mathrm{her}$ to shop steward assistance in individual negotiations, disagreements with management, or in case of being fired. The analysis indicates that shop stewards hold the potential of organizing due to the fact that they can demonstrate a visible difference in 
services between members of the traditional union and non-members. Comparing a case of local-level and sector-level bargaining, this seems especially true for shop stewards who often negotiate at the workplace. However, shop stewards are vulnerable organizers as they depend on the support they receive from other workers. They also depend on support from the local union office as organizing is a time-consuming task. It also seems to weaken the shop stewards possibility to organize if the individual member service delivered by the local union office is dissatisfactory. In the latter case it might in fact be a more rational choice for workers to join an alternative union. In sum, our case study analysis suggests that shop stewards' choice of recruitment and retention strategies is a very reflective choice that considers potential role conflicts between worker, workplace, and union solidarity in each situation. This is why each shop steward makes use of more than one strategy. Further empirical studies are needed to examine the quantitative distribution of the push and pull strategies identified in the case studies and their effects.

\section{References}

Arnholtz, J, Ibsen, F and Ibsen, CL (2012) Importing Low Density Ideas to High Density Revitalization. The Organizing Model in Denmark. Conference paper. $16^{\text {th }}$ World Congress of ILERA, Philadelphia, PA, USA, July 2-5, 2012.

Atkinson, J (1987) 'Flexibility or fragmentation? The United Kingdom labour market in the eighties', Labour and Society 12 (1): 87-105.

Badigannavar, V and Kelly, $\mathrm{J}$ (2005) 'Why are some union organizing campaigns more successful than others?' British Journal of Industrial Relations 43 (3): 515-535.

Badigannavar, V and Kelly, J (2011) 'Partnership and organizing: An empirical assessment of two contrasting approaches to union revitalization in the UK', Economic and Industrial Democracy 32 (1): 5-27.

Chang, TFH (2005) 'Local union leaders' conception and ideology of stewards' roles', Labor Studies Journal 30 (3): 49-71.

Due, J and Madsen JS (1972) Tillidsmanden i klassekampen [Shop Stewards and Class Struggle]. Copenhagen: Forlaget Soc.

Due, J and Madsen, JS (2007) OK2007: Reformforlig i industrien styrker den danske model [Industrial Compromise Strengthens the Danish Model]. Copenhagen: Copenhagen University.

Due, J, Jensen, CS, Madsen, JS and Petersen, LK (1994) The Survival of The Danish Model. Copenhagen: DJØF Publishing.

Due, J, Madsen, JS and Pihl, MD (2010) Udviklingen i den faglige organisering: årsager og konsekvenser for den danske model [Union density developments: causes and effects for the Danish model]. LO-dokumentationen nr. 1. Copenhagen: The Danish Confederation of Trade Unions.

Due, J, Madsen, JS and Ibsen, CL (2012) LO's andel af de fagligt organiserede er for forste gang under 50 pct [Less Than Half of Danish Union Members Are Part of LO]. Copenhagen: Copenhagen University.

Gall, G (2005) 'Organizing non-union workers as trade unionists in the 'New Economy' in Britain', Economic and Industrial Democracy 26 (1): 41-63.

Heckscher, C and Carre, F (2006) 'Strength in networks: employment rights organizations and the problem of co-ordination', British Journal of Industrial Relations 44 (4): 605-628.

Heery, E, Simms, M, Simpson, D, Delbridge, R and Salmon, J (2000) 'Organizing unionism comes to the UK', Employee Relations 22 (1): 38-57. 
Hickey, R, Kuruvilla, S and Lakhani, T (2010): 'No panacea for success: member activism, organizing and union renewal', British Journal of Industrial Relations 48 (1): 53-83.

Hyde, A (2006) 'New institutions for worker representation in the United States: some theoretical issues', New York Law School Law Review 50 (2): 500-531.

Ibsen, CL, Madsen, JS and Due, J (2011) Hvem organiserer sig? Forklaringer på medlemskab af fagforeninger og a-kasser [Who joins a union? Explaining membership of unions and unemployment insurance funds]. LO-dokumentationen nr. 3. Copenhagen: The Danish Confederation of Trade Unions.

Ibsen, F, Høgedahl, L and Scheuer, S (2012) Kollektiv handling. Faglig organisering og skift af fagforening [Collective Action. Joining and Leaving Unions]. Copenhagen: Nyt fra Samfundsvidenskaberne.

Ilsøe, A (2012) 'The flip side of organized decentralization: company-level bargaining in Denmark', British Journal of Industrial Relations 50 (4): 760-781.

Ilsøe, A, Madsen, JS and Due, J (2007) 'Impacts of decentralisation-erosion or renewal? The decisive link between workplace representation and company size in German and Danish industrial relations', Industrielle Beziehungen 14 (3): 201-222.

Justesen, P (2009) Diskrimination på grund af fagforeningsmedlemskab [Discrimination of workers without union affiliation]. Udredning nr. 7. Copenhagen: The Danish Institute for Human Rights.

Larsen, TP, Navrbjerg, SE and Johansen, MM (2010) Tillidsreproesentanten og arbejdspladsen [Shop Stewards and the Workplace]. Copenhagen: The Danish Confederation of Trade Unions.

Lind, J (2009) 'The end of the Ghent system as trade union recruitment machinery?' Industrial Relations Journal 40 (6): 510-523.

Lysgaard, S (1961) Arbejderkollektivet [The Workers' Collective]. Oslo: Universitetsforlaget.

Marsden, D (2004) 'The "Network Economy" and models of the employment contract', British Journal of Industrial Relations 42 (4): 659-684.

Navrbjerg, SE (1999) Nye arbejdsorganiseringer, fleksibilitet og decentralisering [New work organisations, flexibility and decentralization]. PhD Thesis, Copenhagen University, Copenhagen.

Navrbjerg, SE and Larsen, TP (2011): 'De uorganiserede og “de gule”-outsidere med stadig større betydning for samarbejdet på arbejdspladserne’ [Unorganised and alternatively organised workers-outsiders with increasing effects on local cooperation], in: Larsen, TP (ed) Insidere og outsidere. Den danske models rekkevidde. Copenhagen: DJØF Publishing, pp. 83-108.

Oesch, D (2012) 'Recruitment, retention and exit from union membership. An analysis of member flows in Swiss union locals', British Journal of Industrial Relations 50 (2): 287-307.

Olson, M (1965) The Logic of Collective Action. Public Goods and the Theory of Groups. Cambridge, MA: Harvard University Press.

Pilemalm, S, Hallberg, N and Timpka, T (2001) 'How do shop stewards perceive their situation and tasks? Preconditions for support of union work', Economic and Industrial Democracy 22 (4): 569-599.

Tailby, S and Pollert, A (2011) 'Non-unionized young workers and organizing the unorganized', Economic and Industrial Democracy 32 (3): 499-522.

Traxler, F (1995) 'Farewell to labour market associations? Organized versus disorganized decentralisation as a map for industrial relations', in: Crouch, C and Traxler, F (eds) Organized Industrial Relations in Europe: What Future? Aldershot: Avebury, pp. 3-19.

Turberville, SR de (2004) 'Does the "organizing model” represent a credible union renewal strategy?’ Work, Employment and Society 18 (4): 775-794. 
Visser, J (2002) 'Why fewer workers join unions in Europe: a social custom explanation of membership trends', British Journal of Industrial Relations 40 (3): 403-430.

Visser, J (2006) 'Union membership statistics in 24 countries', Monthly Labor Review 129 (1): 38-49.

Walton, RE and McKersie, RB (1965) A Behavioral Theory of Labor Negotiations-An Analysis of a Social Interaction System. New York: McGraw-Hill.

\section{End notes}

${ }^{1}$ Danish unions and unemployment insurance funds are separate organizations. However, each union has historically been administering their own unemployment insurance fund. This means that the Danish labor market in practice can be characterized as a Ghent system, where unions and unemployment insurances are combined (Due et al. 2010; Visser 2006). For many years this strong relation between union activities and unemployment insurance has contributed to the recruitment of union members.

${ }^{2}$ Membership figures reported by the organizations themselves. Source: www.krifa.dk; www. detfagligehus.dk.

${ }^{3}$ The Industrial Agreement is concluded by The Central Organization of Industrial Employees in Denmark (CO-industri) and The Confederation of Danish Industry (DI).

${ }^{4}$ The Collective Agreement for the Food Industry is negotiated between The Danish Food and Allied Workers' Union (NNF) and The Confederation of Danish Industry (DI). 